\title{
Biochemical Changes in Chronic Renal Failure Pre and Post Hemodialysis
}

\author{
Entedhar Rifaat Sarhat ${ }^{1}$ and Nawal Abdullah Murtadha ${ }^{2}$ \\ 1. Department of Basic Science, Dentistry College, University of Tikrit, Tikrit, Iraq \\ 2. Department of Basic science, Dentistry College, University of Kirkuk, Kirkuk, Iraq
}

\begin{abstract}
The aim of the study was to evaluate Paraoxonase-1 (PON-1), resistin and bone mineral markers (Parathyroid Hormone (PTH), $\mathrm{Ca}^{++}$and P) levels as biochemical marker for patients with Chronicrenal Failure (CRF). The sample of this study consists of 100 patients and 100 apparently healthy individuals. All patients were those who were receiving Hemodialysis (HD) therapy in the dialysis unit in Kirkuk general. The levels of PON-1, $\mathrm{Ca}^{++}$were significantly lower in CRF patients pre HD when compared with healthy controls, and significantly increased in post HD as compared to pre HD, but still lower than normal controls. Serum P, resistin and PTH levels were significantly higher in CRF patients pre HD process when compared with healthy controls, and their levels were significantly decreased after HD as compared to pre HD, but remained higher than controls. PON-1 was negatively correlated with the resistin, Blood Urea (BU), Creatinine $(\mathrm{Cr})$, PTH, but positively correlated with $\mathrm{Ca}^{++}$. PON-1 activity was significantly decreased in CRF patients before HD and increased after HD, but remained lower than controls. PON-1 was negatively correlated with the Body Max Index (MBI), resistin, BU, Cr, PTH, but significantly and positively correlated with $\mathrm{Ca}^{++}$.
\end{abstract}

Key words: CRF, HD, PON-1, resistin.

\section{Introduction}

CRF is characterized by progressive loss of renal functionand decline in estimate glomerular filtration rate $[1,2]$. HD is one of the replacement therapy. In this technique, body waste product like urea, $\mathrm{Cr}$ and free water are removed from the blood when the kidneys are impaired [3]. CRF is associated with increased levels of some biochemical parameters and decreased others.

\section{Material and Methods}

A total of 100 patients -55 males, 45 females and 100 healthy individuals -57 males, 43 females from 20-70 years of age were studied. All patients were receiving $\mathrm{HD}$ therapy in the dialysis unit in Kirkuk public hospital from the period between February 2013 and May 2014.

Exclusion criteria: patients with diabetes mellitus,

Corresponding author: Entedhar Rifaat Sarhat, Ph.D., reseach field: clinical biochemistry. schizophrenia, obesity, cancer, Alzheimer's disease, vascular dementia and hepatitis. Blood samples were taken from all cases in the morning between 8-9 a.m. following an overnight fast. The blood samples were centrifuged at 3,500 rpm for 10 minutes, then the serum samples stored at freeze until assayed. Serum resistin and PTH levels were estimated by Enzyme-Linked Immuno Sorbent Assay (ELISA) method. Paraoxonase activity assay was implemented using paraoxon as a substrate conferring to the method described by Mackness, M. [4]. Serum $\mathrm{Ca}^{++}$ and $\mathrm{P}$ levels were determined by flame-photometry. $\mathrm{BU}$ and $\mathrm{Cr}$ levels were measured by spectrophotometric kit. For analysis, the height and weight measurement was used to calculate the BMI as a weight in kilograms divided by height in meter squared $\left(\mathrm{m}^{2}\right)$.

All results are presented as mean \pm SD. Student's t-test was used for the analysis of data. Correlation coefficient used to find the correlation between studied markers by using Pearson correlation. 


\section{Results}

The baseline and demographic characteristics of the subjects of the study population are shown in Table 1. No significant difference was observed between the cases and the controls with respect to their ages and BMI. The average duration of HD therapy for the CRF patients in the present study was $2.19 \pm 0.76$ years.

In the present study, blood urea and serum creatinine showed a significant increase in their levels in patients with CRF before when compared to those of controls. However, the serum PON-1 activity was found to be significantly reduced in patients with CRF before HD than in the controls. After HD, urea and creatinine levels remained at high levels, whereas serum PON-1 activity remained low when compared with control groups.

In the current study, before $\mathrm{HD}$, there was a significant rise in the serum resistin $5 \pm 0.39 \mathrm{ng} / \mathrm{mL}$ when compared with apparently healthy control values of $3.43 \pm 0.26 \mathrm{ng} / \mathrm{mL}$. After HD samples, mean values of resistin $(4.14 \pm 0.15 \mathrm{ng} / \mathrm{mL})$ fail clearly but still higher than the apparently healthy control values $(3.43$ $\pm 0.25 \mathrm{ng} / \mathrm{mL}$ ) as depicted in Table 2 .

This study detected that the serum calcium level was significantly decreased in patient with CRF (1.83 $\pm 0.09 \mathrm{mmol} / \mathrm{L}$ ) before HD when compared with the apparently healthy controls $(2.33 \pm 0.13 \mathrm{mmol} / \mathrm{L})$ and its level increased after HD $(2.00 \pm 0.13 \mathrm{mmol} / \mathrm{L})$, but it remained lower than the controls. Before HD, the serum PTH and P were $41.36 \pm 9.06 \mathrm{pg} / \mathrm{mL}$ and 2.20 $\pm 0.30 \mathrm{mmol} / \mathrm{L}$, respectively, which were significantly higher than the apparently healthy controls of PTH $(19.32 \pm 3.63 \mathrm{pg} / \mathrm{mL})$ and $1.04 \pm 0.15 \mathrm{mmol} / \mathrm{L}$ of $\mathrm{P}$. After HD, both of them showed significantly decreased in their levels, PTH was $29.40 \pm 8.45$ $\mathrm{pg} / \mathrm{mL}$ and $\mathrm{P}$ was $1.89 \pm 0.36 \mathrm{mmol} / \mathrm{L}$, which were also higher than the apparently healthy control in CRF patients.

Table 3 represents that the levels of urea and $\mathrm{Cr}$ significant reduced after the HD were $22.96 \pm 5.70$ $\mathrm{mmol} / \mathrm{L}$ and $0.69 \pm 0.16 \mathrm{mmol} / \mathrm{L}$, respectively. Compared to before HD $(29.40 \pm 6.40) \mathrm{mmol} / \mathrm{L}$ and $(0.90 \pm 0.15) \mathrm{mmol} / \mathrm{L}$, it remained higher than the healthy controls level serum. PON-1 activity also showed a significantly increased after HD (90.62

Table 1 Demographic characteristics of study population.

\begin{tabular}{lll}
\hline & Healthy controls & CRF patients \\
\hline Age (years) (mean $\pm \mathrm{SD})$ & $40.68 \pm 9.58^{*}$ & $48.96 \pm 5.18^{*}$ \\
Sex (males (\%)) & 57 & 55 \\
$($ females $(\%))$ & 43 & 45 \\
Total & 100 & 100 \\
BMI $\left(\mathrm{kg} / \mathrm{m}^{2}\right)$ & $25.74 \pm 1.43^{*}$ & $20.94 \pm 3.29^{*}$ \\
Duration of hemodialysis (years) $=2.19 \pm 0.76$ & \\
${ }^{*} \mathrm{P}<0.05,{ }^{* *} \mathrm{P}<0.01$.
\end{tabular}

Table 2 Biochemical parameters in patients with CRF before and after HD and in apparently healthy controls.

\begin{tabular}{llll}
\hline Biochemicalparameters & $\begin{array}{l}\text { CRF patients before HD } \\
\text { (mean } \pm \mathrm{SD})\end{array}$ & $\begin{array}{l}\text { CRF patients after HD } \\
(\text { mean } \pm \mathrm{SD} \text { ) }\end{array}$ & $\begin{array}{l}\text { Apparently healthy controls } \\
\text { (mean } \pm \text { SD) }\end{array}$ \\
\hline $\mathrm{BU}(\mathrm{mmol} / \mathrm{L})$ & $29.40 \pm 6.40^{*}$ & $22.96 \pm 5.70^{*}$ & $4.53 \pm 0.816$ \\
$\mathrm{Cr}(\mathrm{mmol} / \mathrm{L})$ & $0.90 \pm 0.15^{*}$ & $0.69 \pm 0.16^{*}$ & $0.08 \pm 0.01$ \\
PON1 (IU/L) & $50.02 \pm 6.63^{*}$ & $90.62 \pm 9.14^{*}$ & $149.41 \pm 6.19$ \\
Resistin $(\mathrm{ng} / \mathrm{mL})$ & $5 \pm 0.39^{*}$ & $4.14 \pm 0.15^{*}$ & $3.43 \pm 0.25^{*}$ \\
Parathyroid hormone (pg/mL) & $41.36 \pm 9.06^{*}$ & $29.40 \pm 8.45^{*}$ & $19.32 \pm 3.63^{*}$ \\
Calcium (mmol/L) & $1.83 \pm 0.09^{*}$ & $2.00 \pm 0.13^{*}$ & $2.33 \pm 0.13^{*}$ \\
Phosphorus (mmol/L) & $2.20 \pm 0.30^{*}$ & $1.89 \pm 0.36^{*}$ & $1.04 \pm 0.15^{*}$ \\
\hline
\end{tabular}

${ }^{*} \mathrm{P}<0.05,{ }^{* *} \mathrm{P}<0.01$. 
Table 3 Biochemical parameters in patients with CRF before and after hemodialysis.

\begin{tabular}{lll}
\hline Biochemical parameters & CRF patients before HD $($ mean $\pm \mathrm{SD})$ & CRF patients after HD $(\mathrm{mean} \pm \mathrm{SD})$ \\
\hline Urea $(\mathrm{mmol} / \mathrm{L})$ & $29.40 \pm 6.40^{*}$ & $22.96 \pm 5.70^{*}$ \\
Creatinine $(\mathrm{mmol} / \mathrm{L})$ & $0.89 \pm 5.31^{*}$ & $0.68 \pm 16.30^{*}$ \\
Paraoxonase-1 $(\mathrm{IU} / \mathrm{L})$ & $50.02 \pm 6.63^{*}$ & $90.62 \pm 9.14^{*}$ \\
Resistin $(\mathrm{ng} / \mathrm{mL})$ & $5 \pm 0.39^{*}$ & $4.14 \pm 0.15^{*}$ \\
Parathyroid hormone $(\mathrm{pg} / \mathrm{mL})$ & $41.36 \pm 9.06^{*}$ & $29.40 \pm 8.45^{*}$ \\
Calcium $(\mathrm{mmol} / \mathrm{L})$ & $1.83 \pm 0.09^{*}$ & $2.00 \pm 0.13^{*}$ \\
Phosphorus $(\mathrm{mmol} / \mathrm{L})$ & $2.20 \pm 0.30^{*}$ & $1.89 \pm 0.36^{*}$ \\
\hline
\end{tabular}

${ }^{*} \mathrm{P}<0.05,{ }^{* *} \mathrm{P}<0.01$.

Table 4 Correlation of PON-1 to other parameters.

\begin{tabular}{lllll}
\hline Parameters & Pre HD $(\mathrm{r})$ & $\mathrm{P}$ & Post HD $(\mathrm{r})$ & $\mathrm{P}$ \\
\hline Resistin $(\mathrm{ng} / \mathrm{mL})$ & $-0.348^{*}$ & 0.000 & $-0.272^{*}$ & 0.007 \\
Urea $(\mathrm{mmol} / \mathrm{L})$ & $-0.477^{*}$ & 0.000 & $-0.831^{*}$ & 0.000 \\
Creatinine $(\mathrm{mmol} / \mathrm{L})$ & $-0.843^{*}$ & 0.000 & $-0.783^{*}$ & 0.000 \\
Calcium $(\mathrm{mmol} / \mathrm{L})$ & $0.336^{*}$ & 0.001 & $0.350^{*}$ & 0.000 \\
Phosphorus $(\mathrm{mmol} / \mathrm{L})$ & $-0.234^{*}$ & 0.019 & $-0.295^{*}$ & 0.003 \\
\hline
\end{tabular}

$\pm 9.14) \mathrm{IU} / \mathrm{L}$ as compared to before $\mathrm{HD}(50.02 \pm 6.63)$

$\mathrm{IU} / \mathrm{L}$. There was a significant decreased in mean values of resistin $(4.14 \pm 0.15) \mathrm{ng} / \mathrm{mL}$ after $\mathrm{HD}$ samples in CRF patients as compare to mean values of samples before $\mathrm{HD}(5 \pm 0.39) \mathrm{ng} / \mathrm{mL}(\mathrm{P}<0.05)$.

There were highly significant differences between the levels of serum $\mathrm{Ca}^{++}, \mathrm{P}$ and PTH after HD process, the serum $\mathrm{Ca}$ was $2.00 \pm 0.13 \mathrm{mmol} / \mathrm{L}$ which was significantly higher than its concentration in pre HD $(1.83 \pm 0.09 \mathrm{mmol} / \mathrm{L})$. The mean of serum PTH showed a significantly decreased in its level in post HD stage $(29.40 \pm 8.45 \mathrm{pg} / \mathrm{mL})$ as compared with its concentration before HD $(41.36 \pm 9.06 \mathrm{pg} / \mathrm{mL})$. The level of phosphorus also showed a significantly decreased after HD $(1.89 \pm 0.36 \mathrm{mmol} / \mathrm{L})$ when compared with its concentration in pre HD $(2.20 \pm$ $0.30 \mathrm{mmol} / \mathrm{L}$ ) in patients of CRF disease.

The results presented that the correlation coefficients between serum PON-1 with resistin and the serum bone mineral markers $\left(\mathrm{Ca}^{++}, \mathrm{P}\right.$ and $\left.\mathrm{PTH}\right)$ in CRF patients pre and post HD. There was a strong significant positive correlation between PON-1 and $\mathrm{Ca}^{++}$in both pre $(\mathrm{r}=0.336)$ and post $(\mathrm{r}=0.350) \mathrm{HD}$. Phosphorus showed a significant negative correlation with PON-1 in pre $(r=-0.234)$ and post $(r=-0.295)$ HD. There was a significant negative correlation between PON-1 and PTH in both pre $(r=-0.214)$ and post $(\mathrm{r}=-0.231)$ HD. Resistin showed a strong negative correlation with PON-1 in pre HD $(r=-0.348)$ and significantly negative in post $\mathrm{HD}(\mathrm{r}=-0.272)$ as depicted in Table 4.

\section{Discussion}

Paraoxonase is an enzyme associated with HDL. It has been shown to prevent atherosclerosis by inhibiting oxidation of LDL. Cardiovascular disease is the main cause of mortality and morbidity in patients with CRF and undergoing HD. In this study, the mean activity of PON-1 was lower in patients with CRF before and after HD as compared to apparently healthy controls. Increase in the activities of PON-1 have been evident during post HD as compared to pre HD samples of patients with CRF. The mean activity of PON-1 were decreased before hemodialysis samples of patients with CRF as compared to apparently healthy controls. PON-1 activity was increased in CRF patients during post $\mathrm{HD}$ as compared to pre HD sessions but its concentration is still lower than the normal healthy controls level. This is in accordance with the study of Nagane, N. et al. [5] and Gugliuccil, A. [6]. HD seems to be effective also in raising serum PON-1 activity of the patients. 
PON-1 present in serum is located on HDL, being tightly bound to a HDL subfraction containing apo A-I and clusterin. In CRF, the concentration of middle size and low molecular weight plasma Advanced Glycation End (AGE) products are highly elevated. These AGE residues are formed on long and short lived proteins. Due to low molecular weight, AGE free adducts are easily excreted through the urine. Hence, it acts a good renal clearance tool which distinctly declines in CRF adduct. Retention of AGE free adducts could play a role in decreasing PON-1 activity. During HD procedure, AGE free adducts may be removed, along with the uremic toxins urea and $\mathrm{Cr}$. Thus, the inhibition of PON-1 may be removed.

Resistin is a protein mediator secreted by adipocytes and macrophages within the adipose tissue. Inhumans, resistin is essentially expressed in macrophages from white adipose tissue, rather than in human adipocytes [7]. Plasma resistin level has recently been shown to be associated with markers of Chronic Kidney Disease (CKD), and it is speculated that inflammatory, metabolicand vascular abnormalities associated with increased circulating resistin levels may have a pathogenic role in CKD [8]. The close relationship between GFR and plasma resistin level favors the possibility of reduced filtration of resistin with declining GFR. Nusken, K. D. et al. [9] suggested that renal function is an important factor in the regulation of the systemic levels of resistin. Risch, L. et al. [10] failed, however, to demonstrate an association between GFR and serum resistin at GFR $>60 \mathrm{~mL} / \mathrm{min} / 1.73 \mathrm{~m}^{2}$, suggesting that resistin level in mildly impaired and normal renal function is influenced by factors other than GFR. In the present study, there was a significant increase in the serum level of resistin when compared with their normal values. In post HD samples, the mean values of resistin fail clearly but still higher than the normal control values. These results are compatible with the studies of Axelsson, J. et al., Subhashini, Y., and Kielstein Jan, T. et al. [11-13]. HD does not eliminate resistin as expected for its molecularsize of $12.5 \mathrm{kDa}$ [14].

Chronic renal failure is a gradual, progressive and irreversible loss of normal functioning of kidneys. As the excretory function of kidney is impaired, urea and $\mathrm{Cr}$ excretion is hampered leading to its increased levels in blood, so significant elevation in blood urea and serum creatinine levels are observed in CRF patients before HD. In the present study, the serum urea and creatinine levels were significantly high in pre HD and control groups and was significantly reduced after HD. These results are compatibles with the previous studies $[15,16]$ which explained that the continued decreased in renal clearance or glomerular filtration rate, leads to the gathering of urea, creatinine and other chemicals in the bloodand CRF which applies to the process of containing significant irreversible reduction in the nephron. In CRF, the increase of serum urea is proportional to the progression of the disease, but it is highly influenced by a catabolic state or an excessive protein ingestion, leading to a higher production of other waste substances of protein catabolism [17]. In end-stage kidney disease, HD treatment is applied to remove excess fluid and waste products, such as urea and $\mathrm{Cr}$ from the blood. In this thesis, these parameters show a significant decrease in theirlevels in the post $\mathrm{HD}$ samples for both $\mathrm{BU}$ and serum $\mathrm{Cr}$, but their concentrations were at a higher range than the normal healthy controls levels. These results are in accordance with the study of Baria, D. et al. [18]. These reductions in mean levels of urea and creatinine are observed in the post hemodialysis treatment. The observation is suggestive of clearance of $\mathrm{Cr}$ and urea from blood during HD.

The levels of $\mathrm{P}$ and PTH were significantly increased in CRF in pre HD compared with controls, and they were decreased after HD. Inversely, the serum $\mathrm{Ca}^{++}$was significantly decreased in pre $\mathrm{HD}$ compared with the controls but its concentration was increased in post HD compared with the pre HD. 
These results in the present study are in accordance with the study of Shahbazi, N. et al. [19], Kim, G. H., et al. [20], Collinson, A. et al. [21], and Fouque, D. et al. [22]. The body needs precise regulation of minerals such as phosphorus. Many of organs work together to regulate these levels. The intestines absorb minerals, while the kidneys can excrete them. The parathyroid gland releases parathyroid hormone to regulate phosphorus. The hormone is increased by decreased calcium or increased phosphate. High parathyroid hormone damage the bone and upsets the levels of phosphate and calcium in the bone [23].

Hyperphosphatemia plays a critical role in the development of secondary hyperparathyroidism and renal osteodystrophy in patients with advanced chronic kidney disease as well as patients on dialysis. The usual cause of hyperphosphatemia is a decrease in renal excretion of phosphate. Advanced renal insufficiency reduces excretion sufficiently to increase serum phosphate $\left(\mathrm{PO}_{4}\right)$ [24]. Uremic patients develop hyperplasia of the parathyroid glands due to disturbances in the mineral metabolism [25]. Higher serum intact PTH level is associated with the higher likehood of hyperphosphatemia [26]. Kidney failure is the medical conditions that cause low blood calcium levels or increased phosphate levels can lead to secondary hyperparathyroidism [27].

\section{Conclusion}

PON1 activity was significantly decreased in CRF patients before HD and significantly increased after HD but remained lower than controls. PON1 was negatively correlated with the age, BMI, resistin, $\mathrm{Bu}$, $\mathrm{Cr}$, PTH and P. PON-1 was positively correlated with $\mathrm{Ca}^{++}$. BU and $\mathrm{Cr}$ were increased in CRF patients due to the impairment of kidney function and reduced GFR. The results show that serum resistin are associated with renal impairment in CKD. Longitudinal studies carried out in larger patients cohorts would be helpful in investigation if resistin play a harmful role in the development of CKD, and would enable further understanding of risk factors for CKD progression or its complications (e.g. cardiovascular disease). Hyperphosphatemia, hypocalcemia hyperparathyroidism may have overarching implications on bone and mineral disorders in CRF patients.

\section{References}

[1] Mannangi, N., Jayasree, S. 2014. "Lipoprotein (a) \& Lipid profile in Chronic Kidney Disease, Case Control Study." Webmed Central Biochemistry 5 (2): 2-9. doi:10.9754/journal.wmc.2014.004568.

[2] Coresh, J., Turin, T., and Matsushita, K. 2014. "Decline in Estimated Glomerular Filtration Rate and Subsequent Risk of End-Stage Renal Disease and Mortality." JAMA. 311 (24): 2518-2531. doi:10.1001/jama.2014.6634.

[3] Abram, S., and Anju, V. 2012. "Assessment of Quality of Life in Patient on Hemodialysis and the Impact of Counseling." Saudi Journal of Kidney Disease and Transplantation 23: 953-957.

[4] Mackness, M., and Mackness, B. 2004. "Paraoxonase 1 and Atherosclerosis: Is the Gene or the Protein More Important?" Free Radic. Biol. Med. 37: 1317-1323.

[5] Nagane, N. S., Ganu, J. V. 2011. "Lipid Profile and Serum Paraoxonase-1 Activity in CRF Patients Pre and Post-Hemodialysis." Al. Ameen. J. Med. Sci. 4: 61-68.

[6] Alejandro, G., Kazuhiko, K., and Satoshi, K. 2012 "Paraoxonase-1 in Chronic Kidney Failure." Journal of Lipids 10: 10.

[7] Zein, M. Y., Abdel-Salam, M., Abdel-Aziz, I., and Mohamed, N. F. 2015. "Serum Resistin Level and Polymorphonuclear Leukocytes Dysfunctions in Children on Regular Hemodialysis." International Journal of Clinical Medicine 6: 423-430.

[8] Abou-Youssef, H., Kholoussi, S., Ishak, M., Kholoussi, N., and ElZahraa Ahmed, F. 2013. "Estimation of Resistin in Chronic Kidney Disease." Archives of Hellenic Medicine 30 (2): 212-219.

[9] Nüsken, K. D., Kratzsch, J., Wienholz, V., Stöhr, W., Rascher, W., and Dötsch, J. 2006. "Circulating Resistin Concentrations in Children Depend on Renal Function." Nephrol. Dial. Transplant 21: 107-112. doi:10.1093/ndt/gfi084.

[10] Riscch, L., Saely, C., Hoefle, G., Rein, P., Langer, P., and Gouya, G. et al. 2007. "Relationship between Glomerular Filtration Rate and the Adipokines Adiponectin, Resistinand Leptin in Coronary Patients with Predominantly Normal or Mildly Impaired Renal Function." Clin. Chim. Acta. 376: 108-113. 
[11] Axelsson, J., Bergsten, A., Qureshi, A. R., Heimburger, O., Barany, P., and Lonnqvist, F. et al. 2006. "Elevated Resistin Levels in Chronic Kidney Disease are Associated with Decreased Glomerular Filtration Rate and Inflammation, But Not with Insulin Resistance." Kidney Int. 69: 596-604.

[12] Subhashini, Y. 2007. "Plasma and Urine Levels of Resistin and Adiponectin in Chronic Kidney Disease." Diabetes and Cancer 37 (1): 1-5. doi:10.1155/2012/726048.

[13] Kielstein Jan, T., Björn, B., Susanne, G., Georg, B., and Hermann, H. 2003. "Increased Resistin Blood Levels are not Associated with Insulin Resistance in Patients with Renal Disease." Am. J. Kidney Dis. 42 (1): 62-66.

[14] Kai-Dietrich, N., Jürgen, K., Veronica, W., Wolfgang, S., Wolfgang, R., and Jörg, D. 2005. "Circulating resistin Concentrations in Children Depend on Renal Function." Nephrol Dial Transplant 1 (6): 107-112.

[15] Amin, N., Mahmood, R. T., Asad, M. J., Zafar, M., and Raja, A. M. 2014. "Evaluating Urea and Creatinine Levels in Chronic Renal Failure Pre and Post Dialysis: A Prospective Study." Journal of Cardiovascular Disease 2 (2): 1-4.

[16] Aruna, G., and Ambika Devi, K. 2014. "Evaluation of Thyroid Hormone Status in Chronic Renal Failure." International Journal of Pharma and Bio. Sciences 5 (1): 127-133.

[17] Jumaa, I. 2013. "A Study of Some Biochemical Parameters in Blood Serum of Patients with Chronic Renal Failure." Journal of Basrah Researches 39 (4): 2-32.

[18] Baria, D., and Joshi, V. 2013. "Impact of Hemodialysis on Lipid Profile among Chronic Renal Failure Patients." International Journal of Scientific and Research Publications 3 (7): 2.

[19] Shahbazi, N. 2012. "Variability of Serum Concentration of Calcium, Phosphate and Parathyroid Hormone
Depending on Time of Blood Draw for Patients on Nocturnal Home Hemodialysis." Open Journal of Nephrology 2: 65-71.

[20] Kim, G. H. 2014. "Serum Calcium and Phosphorus Levels Patients Undergoing Maintenance Hemodialysis." Kidney Research and Clinical Practice 33 (1): 52-57.

[21] Collins, A. J., Foley, R. N., Chavers, B., Gilbertson, D., Herzog, C., and Ishani, A. et al. 2014. "US Renal Data System Annual Data Report." Am. J. Kidney Dis. 63 (1): 1-526. doi:10.1053/j.ajkd.11.001.

[22] Fouque, D., Horne, R., Cozzolino, M., and Kalantar-Zadeh, K. 2014. "Balancing Nutrition and Serum Phosphorus in Maintenance Dialysis." Am. J. Kidney Dis. $64 \quad$ (1): $143-50$. doi:10.1053/j.ajkd.2014.01.429.

[23] Fox, J., Lowe, S. H., Petty, B. A., and Nemeth, E. F. 1999. "NPS R-568: A Type II Calcimimetic Compound That Acts on Parathyroid Cell Calcium Receptor of Rats to Reduce Plasma Levels of Parathyroid Hormone and Calcium.” J. Pharmacol. Exp. Ther. 290: 473-479.

[24] Wojcicki, J. M. 2013. "Hyperphosphatemia is Associated with Anemia in Adults without Chronic Kidney Disease: Results from the National Health and Nutrition Examination Survey." BMC Nephrology 14: 178. doi:10.1186/1471-2369-14-178.

[25] Nordholm, A. 2014. "Parathyroid Hormone-Related Peptide Plasma Concentrations in Patients on Hemodialysis." Scandinavian Journal of Clinical \& Laboratory 74 (3): 206-212.

[26] Li Molnar, M. Z., and Zaritsky, J. J. 2013. "Correlates of Parathyroid Hormone Concentration in Hemodialysis Patients." Nephrol. Dial. Transplant 28 (6): 1516-25.

[27] Bringhurst, F. R., Demay, M. B., and Kronenberg, H. M. 2011. "Hormones and Disorders of Mineral Metabolism." In Williams Textbook of Endocrinology, 12th Ed., edited by Kronenberg, H. M., Schlomo, M., Polansky, K. S., and Larsen, P. R. Philadelphia, Pa: Saunders Elsevier. 